\title{
共役てう配法による機械化土工・工程計画管理の最適化 OPTMIZATION OF SCHEDULING AND CONTROL FOR EARTH MOVING BY A CONJUGATE GRADIENT TECHNIQUE
}

\section{1.まえがき}

施工計画・管理業務の合理化を目標として，先に筆者 は，機械化土工工事を具体的な対象とする工程計画管理 最適化問題の定式化を試みた2)。この定式化における基 本的な意図は，機械化土工だけでなく，より一般的な建 設工事の施工を客観的・合理的に表現することである。 この定式化を通じて，建設工事の工程計画管理における 多面的な意志決定問題が「与えられた条件のもとで最も 経済的な施工段取（工程上に扔ける機械・作業員などの 操作方法）に裹づけられた工程計画案の選定」として統 一的に表現されたと考えられる。すなわち，この定式化 において強調されるべきことは次の 2 点である。i）資 源, 資源グループ, オペレーションなどの新しい概念を 導入し，かつ基本的なデータを用いることにより，より 現実に近い形で施工現象が簡潔に表現された。ii）与え られたすべての条件を考慮した上で全体費用を最小にす るといら合理的な評価基準のもとに工程計画を作成する 方法が提案された。このような工程計画手法を筆者は “動的見積り”と称している。

次に, 多段決定過程として定式化された上述の工程計 画最適化問題に対して, 最適制御理論におけるこう配法 を用いた数值解析を行い, 現実的に妥当な数值解が得ら れることを示した ${ }^{3)}$ 。この結果, 上述の動的見積り作業 が実際に可能であることが示された。しかし，こう配法 を適用した際に述べたように, 工程計画最適化問題にお ける制約条件式をペナルティ関数法により処理した上で こう配法を適用する方法については, 計算効率, 解の一 意性などに関する問題が残されている。こう配法による と, 最適解近傍での収束効率が極端に悪くなることか ら, 最適解に到達するまでに非常に多くの反復回数が必 鹿島建設技術研究所主任研究員

** 正会員 工修 鹿島建設技術研究所企画調査室
庄子幹 雄*.荒 井 克 彦** By Mikio Shoji and Katsuhiko Arai

要である。つまり, 決定変数の個数が多い最適化問題に こら配法を適用するためには，きわめて多量の計算が必 要であり, 電子計算機を利用しても, 現実的に妥当な計 算時間で処理できないおそれが強い。したがって，現実 の大規模な建設工事をとり扱らためには不十分である。 そこで本報では，こう配法と比較して一般に効率がよい とされている共役こう配法を用いて，先に定式化された 工程計画最適化問題に対する詳細な数值解析を試みる。 本報で得られる結果により，大型建設工事に対しても現 実的に妥当な計算量で，上述の動的見積り作業を行うこ とが可能になった。

\section{2. 問題の定式化（要約）}

\section{（1） 定式化の準備（記号の定義）}

ここでは工程計画最適化問題の定式化のために直接必 要な変数のみを列挙する。これらの変数の厳密な意味や 求め方などは省略する。詳細については参考文献 2) を 参照されたい。なお，本報で用いる変数のうち，アルフ アベットの大文字で表わした変数はすべて, あらかじめ 与えるべきデータおよび, これらのデータに基づいて直 接計算される変数である。小文字で表わした変数はすべ て, 最適化計算の結果求められる変数（後出の操作変数 ・状態変数) である。ここでは前者について簡単に定義 しておく。

a）工程の表現

以下の変数を用いて, 工程の推移を図一 2 に示す多段 決定過程として表わす。

$T:$ 工期（全体工期）

$N:$ 多段決定過程の全ステージ数

$\Delta T:$ 工期単位（日）

$$
\Delta T=T / N(T=\Delta T \cdot N)
$$

b）要素の定義

以下に導入する要素間の関係を図一1に示す。 


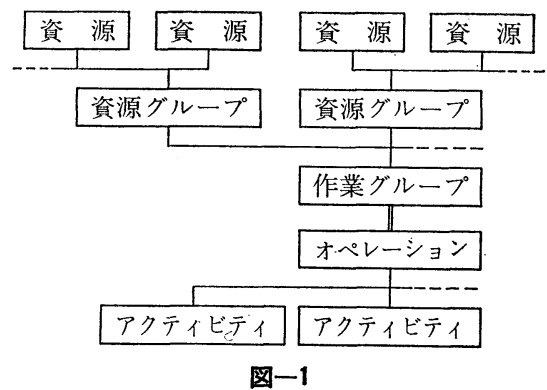

(1) オペレーション (Work Operation) : 表一1 参照 工事 (Project) を表わすための作業である。 $T O Q_{l}:$ オペレーション $l$ の総作業数量

(2) アクティビティ (Activity): 表一1 参照

工程上の作業順序関係の制約を表わせるように，オペ レーションを適当に分割した作業である。

$T Q_{j}$ : アクティビティ $j$ の総作業数量

$A_{l}$ : オペレーションlに属するアクティビティの集

合

$T O Q_{l}=\sum_{j \in A_{l}} T Q_{j}$

(3) 資源 (Resource)：表一2 参照

オペレーションを遂行するために必要な施工機械, 作 業員などの総称であり, 次の 4 つの資源費用成分により 規定される。下添字 $i$ は資源の番号を示す。

$R C D_{i}$ : 固定費用 (円 $/$ 日)

$\mathrm{RCH}_{i}$ : 稼㗢費用 (円 $/$ 時間)

$R C I M_{i}:$ 搬入費用 $($ 円 $/$ 回 $)$

$R C E X_{i}$ : 搬出費用 (円 $/$ 回)

$Q M A X_{i}$ : 利用可能最大数量

(4) 資源グループ (Resource Group)：表一3 参照

常に 1 つのクルー (Crew) として用いられる資源の組 合せであり，次の変数により規定される。下添字 $i$ : 資 源番号, $k:$ 資源グループ番号，とする。

$Q R_{i k}:$ 資源グループにおける資源数量

$U R_{i k}:$ 資源稼働時間率

共用可能性 : 別々の作業で, 並行して同時に利用でき る場合, 共用可能な資源と称する。

(5) 作業グループ (Operation Group)：表一4 参照 オペレーションを遂行するために必要な資源グループ の集合であり，図一1に示すようにオペレーションと 1 対 1 に対応する。

$Q R G_{k l}:$ 作業グループ $l$ に扔ける資源グループ $k$ の数 量

c）作業条件：表一5 参照

$W H_{j}{ }^{n}: 1$ 作業グループ時間当り作業能力

$V M A X_{j}^{n}:$ 最大投入作業グループ数量

$R H_{j}{ }^{n}: 1$ 日当り実稼衝時間
$U D_{j}^{n}:$ (月当り) 稼㗢日数率

ここで, 上添字 $n$ : 図一2 に示す多段決定過程のステ 一ジ番号, 下添字 $j:$ アクティビティ番号, とする。

d) 準備的な変数の計算

定式化の準備として，a)〜c) で与えたデータに基づ いて以下の変数を計算する。

$U O C_{l}$ : オペレーション $l$ 作業数量当り単価

$C T:$ 見積り金額

$$
C T=\sum_{l}\left(U O C_{l} \cdot T O Q_{l}\right)
$$

$U C_{j}$ : アクティビティ $j$ の作業数量当り単価

$$
U C_{j}=U O C_{l}\left(j \in A_{l}\right)
$$

$T C_{j}$ : アクティビティ $j$ の総出来高

$$
T C_{j}=T Q_{j} \cdot U C_{j} / C T \cdot 100(\%),
$$$$
\sum_{j} T C_{j}=100(\%)
$$

$W_{j}^{n}:$ 第 $n$ ステージ・アクティビティ $j$ における 1

作業グループ当り出来高

$$
W_{j}^{n}=W H_{j}^{n} \cdot R H_{j}^{n} \cdot \Delta T \cdot U D_{j}^{n} \cdot U C_{j} l
$$

$$
C T \cdot 100(\%)
$$

$C W_{j}{ }^{n}$ : 第 $n$ ステージ・アクティビティ $j$ イおける 1

作業グループ当り稼㗢費用

$$
\begin{aligned}
C W_{j}^{n}= & \sum_{i}\left\{\sum_{k}\left(Q R_{i k} \cdot U R_{i k} \cdot Q R G_{k l}\right) \cdot R C H_{i}\right\} \\
& \cdot R H_{j}{ }^{n} \cdot \Delta T \cdot U D_{j}{ }^{n},\left(j \epsilon A_{l}\right) \cdots \cdots(7)
\end{aligned}
$$

\section{（2）多段決定過程としての定式化}

図一2 に示す多段決定過程において, $\boldsymbol{\theta}^{n}$ : 自由に操作 しうる操作変数, $\boldsymbol{x}^{n}: \boldsymbol{\theta}^{n}$ を通じてのみ操作しうる状態 変数, $U^{n}$ : 全く操作しえない外乱, とする。これらの変 数は次の状態方程式により関連ゔけられる。

$$
\boldsymbol{x}^{n}=\boldsymbol{f}^{n}\left(\boldsymbol{x}^{n-1}, \boldsymbol{\theta}^{n}, \boldsymbol{U}^{n}\right)
$$

この状態方程式と, 操作変数・状態変数に関する種々の 制約条件を満した上で, ある目的関数の極值を与える操 作変数を求める問題が多段決定過程である。先に定義し た変数を用いて, 工程計画最適化問題が以下のように多 段決定過程（離散型 最 適制御問題）として定式化され る。ただし，定式化に関する詳細な説明は参考文献 2 ) に述べられているので省略し，ここでは概要のみを示 す。定式化の基本的方針を要約すると, 求める解（操作 変数）は「工程上に打ける資源の操作方法 (施工段取)」 であり，この解を決定する基準 (目的関数) は「工事の 全体費用を最小にすること」である。

\section{a) 操作変数 $\theta^{n}$}

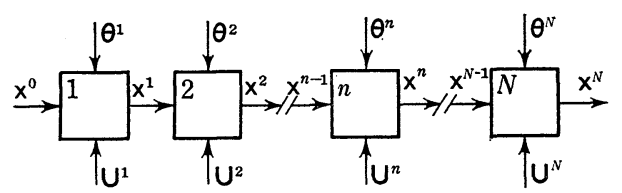

図-2 


$$
\left.\boldsymbol{\theta}^{n}=\left(\begin{array}{l}
\boldsymbol{u}^{n} \\
\boldsymbol{v}^{n}
\end{array}\right), \begin{array}{l}
\left.\boldsymbol{u}^{n}=\left(u_{1}{ }^{n}, \cdots, u_{M^{n}}\right)^{T} \text { 注 } 1\right) \\
\boldsymbol{v}^{n}=\left(v_{1}{ }^{n}, \cdots, v_{L}\right)^{T}
\end{array}\right\} \cdots
$$

$u_{i}{ }^{n}$ : 第 $n$ ステージに扔ける資源 $i$ の搬入 $\left(u_{i}{ }^{n}>0\right)$,

$$
\text { 搬出 }\left(u_{i}^{n}<0\right) \text { 数量 }
$$

$\tilde{v}_{j}^{n}:$ 第 $n$ ステージ・アクティビティ $j$ に扔ける作業 グループ投入数量

b） 状態変数 $\boldsymbol{x}^{n}$ と状態方程式

$$
\left.\boldsymbol{x}^{n}=\left(\begin{array}{c}
\boldsymbol{q}^{n} \\
\boldsymbol{r}^{n} \\
x_{2}{ }^{n}
\end{array}\right) \begin{array}{l}
q^{n}=\left(q_{1}{ }^{n}, \cdots, q_{M^{n}}\right)^{T} \\
\boldsymbol{r}^{n}=\left(r_{1}{ }^{n}, \cdots, r_{L}{ }^{n}\right)^{T}
\end{array}\right\}
$$

$q_{i}{ }^{n}$ : 第 $n$ ステージにおける資源 $i$ の存置数量

$r_{j}^{n}$ : 第 $n$ ステージに拉けるアクティビティ $j$ の累積 出来高

$x_{2}{ }^{n}$ : 第 $n$ ステージにおける全累積費用

$$
\begin{aligned}
q_{i}{ }^{n} & =q_{i}{ }^{n-1}+u_{i}{ }^{n}, \quad(i=1, \cdots, M) \cdots \cdots \cdots \\
r_{j}{ }^{n} & =r_{j}{ }^{n-1}+W_{j}^{n} \cdot v_{j}{ }^{n}, \quad(j=1, \cdots, L)
\end{aligned}
$$

ただし

$$
\begin{aligned}
& x_{2}{ }^{n}=x_{2}{ }^{n-1}+\sum_{i}\left\{R C D_{i} \cdot \Delta T \cdot\left(q_{i}{ }^{n-1}+u_{i}{ }^{n}\right)\right. \\
& \left.+R C I M_{i} \cdot V\left[u_{i}^{n}\right]+R C E X_{i} \cdot V\left[-u_{i}^{n}\right]\right\} \\
& +\sum_{j}\left\{C W_{j}^{n} \cdot v_{j}^{n}\right\}
\end{aligned}
$$

$$
\left.\begin{array}{rl}
V[x] & =x: x>0 \\
& =0: x \leq 0
\end{array}\right\}
$$

境界条件

$$
\begin{aligned}
& \boldsymbol{q}^{0}=\mathbf{0}, \boldsymbol{r}^{0}=\mathbf{0}, x_{2}{ }^{0}=0 \\
& r_{j}{ }^{N}=T C_{j}, \quad(j=1, \cdots, L)
\end{aligned}
$$

状態変数ではないが，第 $n$ ステージにおける全累積出来 高 $x_{1}{ }^{n}$ を次式で定義する。

$$
\left.\begin{array}{l}
x_{1}{ }^{n}=x_{1}{ }^{n-1}+\sum_{j}\left(W_{j}{ }^{n} \cdot v_{j}{ }^{n}\right) \\
x_{1}{ }^{0}=0, x_{1}{ }^{N}=100(\%)
\end{array}\right\}
$$

c) 制約条件

$$
\begin{aligned}
& 0 \leq q_{i}^{n} \leq Q M A X_{i}, \quad(i=1, \cdots, M) \cdots \cdots \cdots(18) \\
& \sum_{j}\left(h_{i l} \cdot v_{j}^{n}\right) \leq q_{i}^{n},\left(j \in A_{l}, i=1, \cdots, M\right) \cdots(19) \\
& 0 \leq v_{j}^{n} \leq V M A X_{j}{ }^{n},(j=1, \cdots, L) \cdots \cdots(20) \\
& r_{j}^{n} \leq T C_{j}, \quad(j=1, \cdots, L) \cdots \cdots \cdots \cdots \cdots \cdots \cdots(21) \\
& v_{j}^{n} \cdot\left(r_{k}^{n-1}-T C_{k}\right)=0,\left(k \in P_{j}, \quad j=1, \cdots, L\right)
\end{aligned}
$$

\begin{tabular}{|c|c|c|c|c|c|c|}
\hline No. & \multirow[t]{2}{*}{ 資源名称 } & $\begin{array}{l}\text { 固定費用 } \\
\left(R C D_{i}\right)\end{array}$ & $\mid \begin{array}{l}\text { 稼働費用 } \\
\left(R C H_{i}\right)\end{array}$ & $\begin{array}{l}\text { 搬入費用 } \\
\left(R C I M_{i}\right)\end{array}$ & $\begin{array}{l}\text { 搬出費用 } \\
\left(R C E X_{i}\right)\end{array}$ & $\begin{array}{l}\text { 利用可能 } \\
\text { 最大数量 } \\
\left(Q M A A X_{i}\right)\end{array}$ \\
\hline & & 円 $/$ 日 & 円／時間 & 円/回 & 円 /回 & \\
\hline 1 & ブルドーザ & 11,600 & 5,020 & 107,600 & 107,600 & 10 \\
\hline 2 & フルドーザ & 24,000 & 9,000 & 120,000 & 120,000 & 10 \\
\hline 3 & ブルドーザ & 35,200 & 10,880 & 131,200 & 131,200 & 10 \\
\hline 4 & $\begin{array}{l}\text { フルドーザ } \\
\text { D-8-36AC }\end{array}$ & 30,400 & 6,920 & 126,400 & 126,400 & 10 \\
\hline 5 & スクレーパ 18 & 13,200 & 700 & 80,000 & 80,000 & 10 \\
\hline 6 & $\begin{array}{c}\text { フルドーザ } \\
\text { D-8-46AC }\end{array}$ & 41,000 & 8,700 & 137,000 & 137,000 & 10 \\
\hline 7 & スクレーパ 22 & 14,800 & 700 & 80,000 & 80,000 & 10 \\
\hline
\end{tabular}

\begin{tabular}{|c|c|c|c|c|c|}
\hline $\begin{array}{l}\text { No. } \\
(k)\end{array}$ & 源 & 源 & $\begin{array}{l}\text { 資源数量 } \\
\left(Q R_{i k}\right)\end{array}$ & 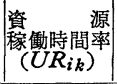 & 昔用能性 \\
\hline 1 & A & $\begin{array}{l}\text { ブルドーザ D-80 } \\
\text { フルドーザ D-8-36A }\end{array}$ & $\begin{array}{l}1.0 \\
1.0\end{array}$ & $\begin{array}{l}1.0 \\
1.0\end{array}$ & $\begin{array}{l}\text { 可 } \\
\text { " }\end{array}$ \\
\hline 2 & B & $\begin{array}{ll}\text { ブルドーザ } & \text { D-80 } \\
\text { フルドーザ } & \text { D-8-36A } \\
\text { ブルドーザ } & \text { D-8-46A }\end{array}$ & $\begin{array}{l}1.0 \\
1.0 \\
1.0\end{array}$ & $\begin{array}{l}0.8 \\
1.0 \\
1.0\end{array}$ & " \\
\hline 3 & C & $\begin{array}{l}\text { フルドーザ D-8-46A } \\
\text { フルドーザ D-8-36AC } \\
\text { スクレーパ } 18 \\
\text { フルドーザ } \mathrm{D}-8-46 \mathrm{AC} \\
\text { スクレーパ } 22\end{array}$ & $\begin{array}{l}1.0 \\
1.0 \\
1.0 \\
1.0 \\
1.0\end{array}$ & $\begin{array}{l}0.5 \\
1.0 \\
1.0 \\
1.0 \\
1.0\end{array}$ & $\begin{array}{l}\text { 不可 } \\
\text { " } \\
\text { " } \\
\text { " }\end{array}$ \\
\hline 4 & D & フルドーザ D-80 & 1.0 & 1.0 & 可 \\
\hline
\end{tabular}

ここで, $P_{j}:$ アクティビティ $j$ の先行アクティビティ の集合とし，また

$$
\begin{aligned}
& h_{i l}=\sum_{k}\left(Q R_{i k} \cdot U R_{i k} \cdot Q R G_{k l}\right) \text { : 共用資源 } \\
& =\sum\left(Q R_{i k} \cdot Q R G_{k l}\right) \quad \text { : 非共用資源 }
\end{aligned}
$$

表-1 作 業 数

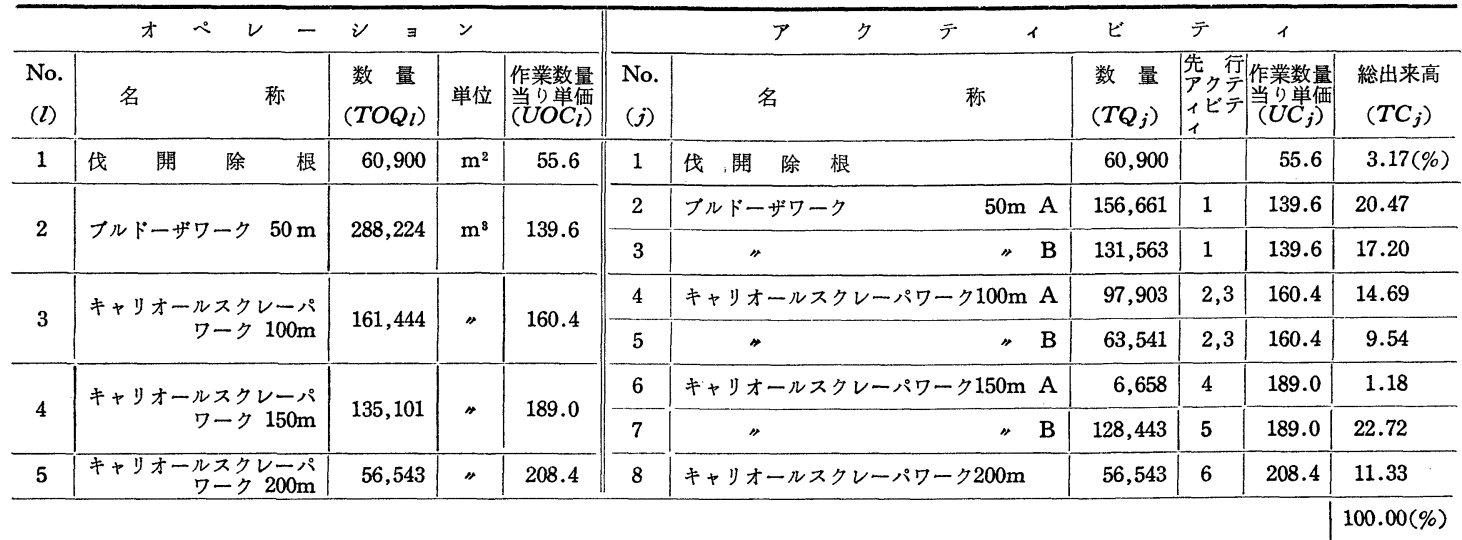

表一2 資 源単価 表

注 1）転置行列を表わす。
表一3 資源グルーブ 
表一5 作 業 条 件

\begin{tabular}{|c|c|c|c|c|c|c|c|c|c|}
\hline \multirow{3}{*}{$\begin{array}{l}\text { No. } \\
(j)\end{array}$} & \multirow{3}{*}{ アクティビティ名称 } & \multirow{3}{*}{ 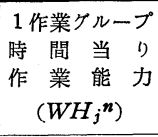 } & \multirow{3}{*}{ 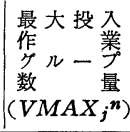 } & \multirow{3}{*}{$\begin{array}{c}1 \text { 日当 }) \\
\text { 実稼働時間 } \\
\left(R H_{j}{ }^{n}\right)\end{array}$} & \multicolumn{5}{|c|}{ 稼 働 日 数率 $\left(U D_{j}{ }^{n}\right) \Delta T=5$ 日 } \\
\hline & & & & & 1 月 & 2 月 & 3 月 & 4 月 & 5 月 \\
\hline & & & & & $n=1 \sim 6$ & $7 \sim 12$ & $13 \sim 18$ & $19 \sim 24$ & $25 \sim 30$ \\
\hline 1 & 伐 開 除 根 & $335\left(\mathrm{~m}^{2} / \mathrm{hr}\right)$ & 5 & $12(\mathbf{h r})$ & 0.68 & 0.75 & 0.60 & 0.62 & 0.57 \\
\hline 2 & プルドーザワーク $50 \mathrm{~m} \mathrm{~A}$ & $235\left(\mathrm{~m}^{3} / \mathrm{hr}\right)$ & 10 & $12(" \prime)$ & 0.68 & 0.75 & 0.60 & 0.62 & 0.57 \\
\hline 3 & B & $235(")$ & 10 & $12(" \prime)$ & 0.68 & 0.75 & 0.60 & 0.62 & 0.57 \\
\hline 4 & キャリオールスクレーパワーク $100 \mathrm{~m} \mathrm{~A}$ & $320(")$ & 10 & $12(" \prime)$ & 0.68 & 0.75 & 0.60 & 0.62 & 0.57 \\
\hline 5 & $"$ & $320(")$ & 10 & $12(")$ & 0.68 & 0.75 & 0.60 & 0.62 & 0.57 \\
\hline 6 & キャリオールスクレーパワーク $150 \mathrm{~m} \mathrm{~A}$ & $268(" \prime)$ & 10 & $12(")$ & 0.68 & 0.75 & 0.60 & 0.62 & 0.57 \\
\hline 7 & $"$ & $268(")$ & 10 & $12(")$ & 0.68 & 0.75 & 0.60 & 0.62 & 0.57 \\
\hline 8 & キャリオールスクレーパワーク $200 \mathrm{~m}$ & $240(")$ & 10 & $12(")$ & 0.68 & 0.75 & 0.60 & 0.62 & 0.57 \\
\hline
\end{tabular}

表-4 作業グループ

\begin{tabular}{|c|c|c|c|c|}
\hline $\begin{array}{l}\text { No. } \\
(l)\end{array}$ & 作業クループ名称 & $\begin{array}{l}\text { 資源ケループ } \\
\text { 名 称 }\end{array}$ & $\begin{array}{l}\text { 疽源 ケループ } \\
\left(Q R G_{k l}\right)^{\text {量 }}\end{array}$ & $\begin{array}{l}\text { 比例型 } \\
\text { 固定型 }\end{array}$ \\
\hline 1 & 伐 開 除 根 & A & 1.0 & 比例 \\
\hline 2 & ブルドーザワーク $50 \mathrm{~m}$ & B & 1.0 & $"$ \\
\hline 3 & $\begin{array}{r}\text { キャリオールスクレーパ } \\
\text { ワーク } 100 \mathrm{~m}\end{array}$ & $\begin{array}{l}\mathrm{C} \\
\mathrm{D}\end{array}$ & $\begin{array}{l}1.0 \\
0.9\end{array}$ & " \\
\hline 4 & $\begin{array}{r}\text { キャリオールスクレーパ } \\
\text { ワーク } 150 \mathrm{~m}\end{array}$ & $\begin{array}{l}\mathrm{C} \\
\mathrm{D}\end{array}$ & $\begin{array}{l}1.0 \\
0.8\end{array}$ & " \\
\hline 5 & $\begin{array}{r}\text { キャリオールスクレーパ } \\
\text { ワーク } 200 \mathrm{~m}\end{array}$ & $\begin{array}{l}\mathrm{C} \\
\mathrm{D}\end{array}$ & $\begin{array}{l}1.0 \\
0.7\end{array}$ & " \\
\hline
\end{tabular}

d) 目的関数

$J=x_{2}{ }^{N}+\sum_{i}\left(R C E X_{i} \cdot q_{i}{ }^{N}\right) \rightarrow \min$

\section{（3）数值計算モデル}

本報の数值計算モデルとしては, 計算結果の比較など の都合により, 先にこう配法の適用に際して用いた数值 計算モデルをそのまま利用する3）。具体的な数值を表一 1 5 に示す。

\section{3. 共役こう配法による最適化}

\section{（1）共役こう配法}

最適制御問題に用いる共役こう配法 (Conjugate Gradient Technique) も, こう配法と同様に, 静的最適化 問題 (変数空間における最適化問題) に対して開発され た共役こう配法を関数空間における最適化問題に対して 拡張したものである。静的最適化問題に対する共役こう 配法として一般に用いられるのは Fletcher-Reeves の 方法 (FR 法) ${ }^{32}$, Davidon-Fletcher-Powell の方法

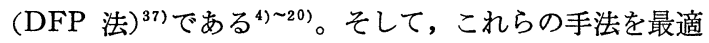
制御問題に適用するための多数の報告がなされている33) 36),38),399。一般に DFP 法, FR 法, こう配法の順で 収束が速いとされており，また DFP 法, FR 法ともに 1 回の試行に要する計算量が Newton-Raphson 法ほど 多くないので比較的多变数の最適化問題に適用すること
が可能である。しかし DFP 法は試行の途中できわめて 大きな記憶容量を必要とするので, 適用しうる問題の決 定変数の個数に制限がある。FR 法では試行中に必要な 記憶量がこう配法におけるのとほとんど変らないので, 先に定式化された工程計画最適化問題に対しても十分適 用可能である。そこで本報では FR 法 (以下, 単に共役 こう配法と称する）を採用することにし，離散型最適制 御問題に対する FR 法の計算アルゴリズムを以下に引用 する ${ }^{33)}$ 。

(a) 操作変数 $\boldsymbol{\theta}^{n}$ の初期解 $\boldsymbol{\theta}_{0}{ }^{n}$ を与える。

(b) こう配関数 $\left(\partial H_{0}{ }^{n} / \partial \boldsymbol{\theta}_{0}{ }^{n}\right)$ を計算する。

(c) $\boldsymbol{s}_{0}{ }^{n}=-\left(\partial H_{0}{ }^{n} / \partial \boldsymbol{\theta}_{0}{ }^{n}\right)$ とする。

(d) $\boldsymbol{\theta}_{k}{ }^{n}$ を次式により修正する。

$$
\boldsymbol{\theta}_{k+1}^{n}=\boldsymbol{\theta}_{k}{ }^{n}+\alpha_{k} \cdot \boldsymbol{s}_{k}{ }^{n}
$$

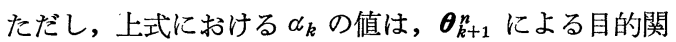
数の值が極小になるように選ぶものとする。

(e ) こう配関数 $\left(\partial H_{k+1}^{n} / \partial \boldsymbol{\theta}_{k+1}^{n}\right)$ を計算する。

(f) 次式から $\beta_{k}$ を求める。

$$
\begin{array}{r}
\beta_{k}=\sum_{n}\left\{\left(\frac{\partial H_{k+1}^{n}}{\partial \boldsymbol{\theta}_{k+1}^{n}}\right)^{T} \cdot\left(\frac{\partial H_{k+1}^{n}}{\partial \boldsymbol{\theta}_{k+1}^{n}}\right)\right\} \\
/ \sum_{n}\left\{\left(\frac{\partial H_{k}{ }^{n}}{\partial \boldsymbol{\theta}_{k}}\right)^{T} \cdot\left(\frac{\partial H_{k}{ }^{n}}{\partial \boldsymbol{\theta}_{k}}\right)\right\}
\end{array}
$$

(g) 次式により $\boldsymbol{s}_{k}{ }^{n}$ を修正する。

$$
\boldsymbol{s}_{k+1}^{n}=-\left(\partial H_{k+1}^{n} / \partial \boldsymbol{\theta}_{k+1}^{n}\right)+\beta_{k} \cdot \boldsymbol{s}_{k}{ }^{n}
$$

(h) 計算停止基準を満すまで $(\mathrm{d}) \sim(g)$ を繰返す。

\section{（2）共役こう配法の適用}

共役こう配法を用いる場合, 式（16）に示すような終 端拘束条件に対しては Kelley の方法 (等式制約条件と みてペナルティ関数法を適用する ${ }^{30)}$ 以外に適当な 処理 方法がない。ここでは終端拘束条件に対して Kelley の 方法を, 式 (18) （22）の不等式, 等式制約条件に対し $\tau$ SUMT (Sequential Unconstrained Minimization Technique) ・ 外点法 ${ }^{25}$ を用いて, 工程計画最適化問題 を制約条件のない最適化問題に変換した上で共役こう配 法を適用する。

a）適用の準備 
初めに, 収束効率改善のためのスケール変換として, 費用の尺度を次のように変換する ${ }^{3)}$ 。

1 円 $\Leftrightarrow 100(\%) /$ 見積り金額 $(C T)$

次に, SUMT ・ 外点法による試行途上で, 資源存置数 量 $q_{i}{ }^{n}$ が極端な負值をとり最適解から大きく外れること を防ぐために，式 (13)，(24) における $q_{i}{ }^{n} を V\left[q{ }^{n}\right]$ で置き換える ${ }^{3)}$ 。

不等式，等式制約条件にそれぞれ対応するペナルティ 項 $P I^{n}, P E^{n}$ に関する状態方程式が次式で与えられる。

$$
\begin{aligned}
P I^{n}= & P I^{n-1}+\sum_{i}\left\{W\left[q_{i}{ }^{n}-Q M A X_{i}\right]\right. \\
& \left.+W\left[-q_{i}{ }^{n}\right]+W\left[\sum_{j}\left(h_{i l} \cdot v_{j}{ }^{n}\right)-q_{i}{ }^{n}\right]\right\} \\
& +\sum_{j}\left\{W\left[r_{j}{ }^{n}-T C_{j}\right]\right\} \quad \cdots \cdots \cdots \cdots \cdots \cdots(29) \\
P E^{n}= & P E^{n-1}+\sum_{j}\left\{\left(v_{j}{ }^{n}\right)^{2} \cdot \sum_{k \in P_{j}}\left(r_{k}{ }^{n-1}-T C_{k}\right)^{2}\right\}
\end{aligned}
$$

$$
P I^{0}=P E^{0}=0
$$

ここで

$$
\left.\begin{array}{rl}
W[x]=x^{2} \cdot H[x], H[x] & =1: x>0 \\
& =0: x \leq 0
\end{array}\right\}
$$

以上の準備に基づき, SUMT ・ 外点法における修正目 的関数が次式で与えられる。

$$
\begin{aligned}
P\left\{\boldsymbol{\theta}^{n}, \lambda\right\}= & x_{2}{ }^{N}+\sum_{i}\left\{R C E X_{i} \cdot V\left[{q_{i}}^{N}\right]\right\} \\
& +\lambda_{1} \cdot P I^{N}+\lambda_{2} \cdot P E^{N} \\
& +\lambda_{3} \cdot \sum_{j}\left(r_{j}{ }^{N}-T C_{j}\right)^{2} \rightarrow \min
\end{aligned}
$$

ここで, $\lambda_{1}, \lambda_{2}, \lambda_{3}$ はそれぞれのペナルティ項に対応する ペナルティ係数とし，これらの值を逐次的に増加させる ことにより，最終的に制約条件を満す最適解を得る方法 が SUMT・外点法である ${ }^{5(13), 20) ~ 28) 。 ~}$

\section{b) 計 算 式}

共変変数 $\boldsymbol{z}^{n}$, こう配関数 $\left(\partial H^{n} / \partial \boldsymbol{\theta}^{n}\right)$ がそれぞれ次の ように計算される ${ }^{3)}$ 。

$$
\begin{aligned}
z_{q_{i}}{ }^{N}= & R C E X_{i} \cdot H\left[{q_{i}}^{N}\right], \quad(i=1, \cdots, M) \cdots(34) \\
z_{q_{i}}{ }^{n-1}= & z_{q_{i}}{ }^{n}+R C D_{i} \cdot \Delta T \cdot H\left[q_{i}{ }^{n}\right] \\
& +2 \lambda_{1} \cdot\left\{V\left[{q_{i}}^{n}-Q M A X_{i}\right]-V\left[-q_{i}{ }^{n}\right]\right. \\
& \left.-V\left[\sum_{j}\left(h_{i l} \cdot v_{j}{ }^{n}\right)-{q_{i}}^{n}\right]\right\}, \quad(i=1, \cdots, M)
\end{aligned}
$$

$$
\begin{aligned}
& z_{r_{j}}{ }^{N}= 2 \lambda_{3} \cdot\left(r_{j}{ }^{N}-T C_{j}\right),(j=1, \cdots, L) \cdots( \\
& z_{r_{j}}{ }^{n-1}= z_{r_{j}}{ }^{n}+2 \lambda_{1} \cdot V\left[r_{j}{ }^{n}-T C_{j}\right] \\
&+2 \lambda_{2} \cdot\left(r_{j}{ }^{n-1}-T C_{j}\right) \cdot \sum_{k \in S_{j}}\left(v_{k}{ }^{n}\right)^{2}, \\
&(j=1, \cdots, L) \quad \cdots \cdots \cdots \cdots \cdots \cdots \cdots \cdots \cdots \\
& \partial H^{n} / \partial u_{i}{ }^{n}=z_{q_{i}}{ }^{n}+R C D_{i} \cdot \Delta T \cdot H\left[{q_{i}}^{n}\right] \\
&+ \\
&+R C I M_{i} \cdot H\left[u_{i}{ }^{n}\right]-R C E X_{i} \cdot H\left[-u_{i}{ }^{n}\right] \\
&+2 \lambda_{1} \cdot\left\{V\left[q_{i}{ }^{n}-Q M A X_{i}\right]-V\left[-q_{i}{ }^{n}\right]\right. \\
&\left.-V\left[\sum_{j}\left(h_{i l} \cdot v_{j}{ }^{n}\right)-q_{i}{ }^{n}\right]\right\}, \quad(i=1, \cdots, M)
\end{aligned}
$$

$$
\begin{aligned}
& +2 \lambda_{1} \cdot\left[\sum_{i}\left\{h_{i l} \cdot V\left[\sum_{k}\left(h_{i l} \cdot v_{k}{ }^{n}\right)-q_{i}^{n}\right]\right\}\right. \\
& \left.+W_{j}^{n} \cdot V\left[r_{j}^{n}-T C_{j}\right]\right] \\
& +2 \lambda_{2} \cdot\left\{v_{j}^{n} \cdot \sum_{k \in P_{j}}\left(r_{k}^{n-1}-T C_{k}\right)^{2}\right\},(j=1, \cdots, L)
\end{aligned}
$$

ここで, $S_{j}$ : アクティビティ $j$ の後続アクティビティ の集合とする。

\section{（3） 数值計算結果}

表一1〜5 に示した数值計算モデルに対して SUMT・ 外点法と共役こう配法を適用した結果は以下の通りであ る。

a) 1 次元探索

式 (25) に括ける $\alpha_{k}$ の決定は, 目的関数が 2 次形式 である場合を除いて，いわゆる1次元探索によらなけれ ばならない。黄金分割法による1 次元探索 ${ }^{17), 29)}$ と佐山 らによる便宜的な方法 $\left(\alpha_{k}\right.$ の值を逐次的に 2 倍または $1 / 2$ 倍して目的関数值を最小にする $\alpha_{k}$ の值をはさみ, 2 次関数近似を行う $)^{5), 22)}$ とを比較したところ, 各試行 に㧍ける $\alpha_{k}$ の值は両方法により多少の差があるにして も, 収束効率, 経路はほとんど同一であった。そこで以 下では, 前者に比べて計算量の少ない後者を採用する。

b) 操作変数制約条件の処理

初期解を $\boldsymbol{u}^{n}=\boldsymbol{v}^{n}=\mathbf{0}$ とし, ペナルティ係数 $\lambda_{1}=\lambda_{2}=$ $\lambda_{3}=0.1$ としたときの, 修正目的関数 $P\left\{\boldsymbol{\theta}^{n}, \lambda\right\}$ の収束 の様子を図一 3 に示す。

図一3における共役こう 配法Aは, こう配法の適 用に際して行ったのと同

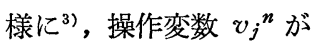
式 (20) の制約領域を越 すときは単純にその境界 值を与えて試行を繰り返 した結果である。共役こ ら配法を最適制御問題に 適用する場合に, 操作変 数だけから成る制約条件

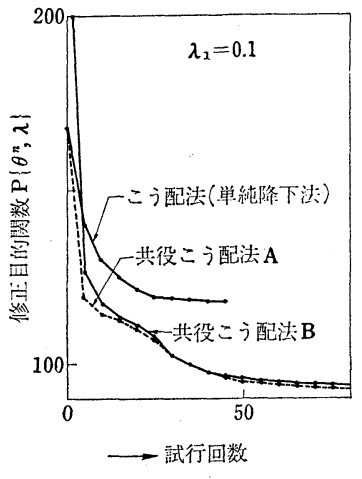

図一3 式を上述のように単純に処理すると, 真の最適解とは異 なる解に収束する可能性が指摘されている ${ }^{34)}$ 。そこで, 式（20）についてもペナルティ関数法を適用して収束計 算を行った結果が 図一3 における共役こう配法 B であ る。この例からも明らかなように共役こう配法 A,B は同じよらな経路をたどり, ほとんど同一の解に収束す る。したがって工程計画最適化問題では, 操作変数の制 約を上述のように単純に処理してさしつかえないと判断 されるので以下では共役こう配法Aを採用する。

c）修正共役こう配法 
一般に $m$ 変数の静的最適化問題に共役こう配法を適 用する場合, 丸めの誤差の累積を防ぐために, 式 (27) の $\boldsymbol{s}_{m+1}$ として $(m+1)$ 回目の試行におけるこう配に (-1) を乗じた值をとる のが数值計算上有効とさ れている51,13)。そこで, 工程計画最適化問題にお ける各ステージの操作変 数の個数 $(M+L)$ 回の 試行ごとに, 式 (27) に おける $\beta_{k}=0$ として試行 を繰り返す方法（仮に修 正共役こう配 法と称す

る）を適用したところ， 図一4に示すように収束

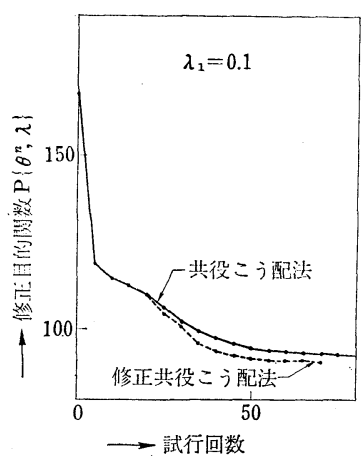

图-4

点付近の収束効率が著しく改善された。

d) SUMT · 外点法の適用

ペナルティ係数 $\lambda_{1} \sim \lambda_{3}$ の值を増加させた場合，こう 配法によると収束がきわめて遅くなることを指摘してお いたが ${ }^{3)}$ ，共役こう配法による場合はペナルティ係数值 に関係なく常に良好な収束結果が得られた。その理由と して,こう配法の収束効率, 目的関数㧍よび制約条件式 から定義されるへシアン行列の特性，およびペナルティ 係数值の間に支配的な関係がある こと, そして共役こう配法がこの 影響を受けないことが明らかにさ れている23),24)。

また図一3から明らかなよう に, 共役こう配法により,こう配 法では到達しえない解が得られる ことも強調されるべきであろう。

常に $\lambda_{1}=\lambda_{2}=\lambda_{3}$ として SUMT

・外点法を適用した結果を 図一5 に示す。図一6 は各ペナルティ係 数值に対応する出来高曲線を示

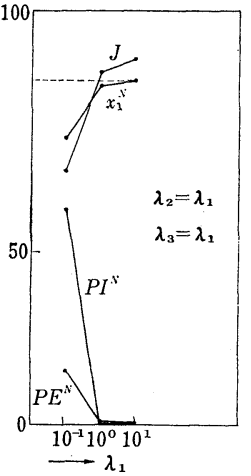

図-5

す。こら配法を用いた場合, 等式, 不等式制約条件違反 量に対応する $P E^{N}, P I^{N}$ を十分 0 に近ゔけるには, ペ

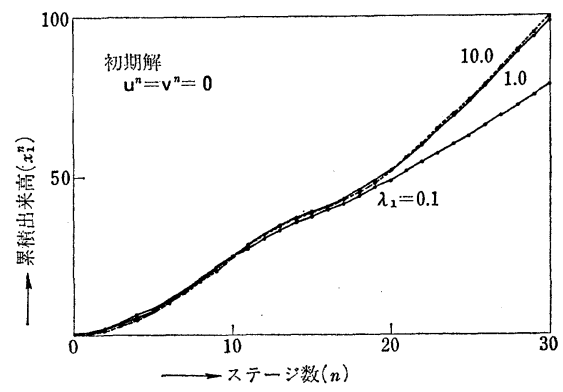

図-6
ナルティ係数值を $10^{4}$ 程度まで増加させる必要がある が3)，共役こう配法による場合は倸数值が 10 程度で近 似的に制約条件を満す最適解が得られる。このことは言 算量の減少だけでなく, SUMT・外点法においてペナル ティ係数值の増大に伴って生じる，いわゆる ill-condi tion $^{5), 26)}$ の影響が小さくなることも意味している。ま た，本報の数值計算モデルに関する限り，ペナルティ售 数值の初期値や増加率を変えても顕著な勃果がみられな かったことを付記しておく。

以上の結果功判断して, 工程計画最適化問題に対し ても, 共役こう配法がこう配法に比べて格段に優れた手 法であると結論できる。

\section{4. 解空間の特性に関する検討}

\section{（1） SUMT・外点法による結果}

\section{a）こう配法による解との比較}

こう配法を用いた数值解析を行った際に, 終端拘束 条件に対して Bryson・Denham の方法 ${ }^{5) ~ 8), 31) ， K e l l y ~}$ の方法をそれぞれ適用した解が，両者とも SUMT・外 点法を用い, $\boldsymbol{u}^{n}=\boldsymbol{v}^{n}=0$ を初期解としたにもかかわらず

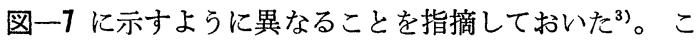
れは式 (33) の修正目的関数が狭義の凸関数 (Strictly Convex Function) ではないことに起因して, 前者は上 方から, 後者は下方から解曲線に近づくために, それぞ れ異なる解に収束したものと推定された。一方, 前述の 上うに, Kelley の方法, SUMT・外点法, 共役こう配 法の適用により得られた出来高曲線（図一6）は図一7 に示すように，こう配法による $2 つ の$ 結果の中間の解曲 線を与える。図一3 から明らかなように，共役こう配法 によりこう配法では到達しえない解が得られると推察さ れるので, 図一7においても共役こう配法による解曲線 がこう配法 (Kelley の方法) による解よりは数值計算上 妥当な結果である可能性が強い。しかし Bryson・Denham の方法による解との間には，まだかなりの差があ り，この差が目的関数の広義の凸性に起因するものかど らかが明らかでない。以下で SUMT による解の特性に

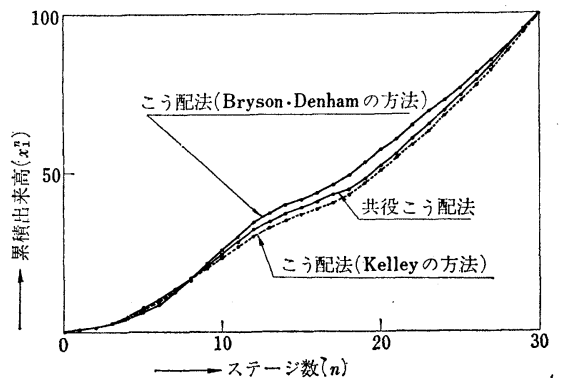

図-7 
関する数值解析上の検討を行う。

b） SUMT・外点法，共役こう配法による凸性の検討 $\mathrm{SUMT} \cdot$ 外点法, 共役こう配法を適用し, $\boldsymbol{u}^{n}, \boldsymbol{v}^{n}$ の 初期解にある程度大きな值を与えて, 図一6 の場合とは 逆に上方から解曲線に近ゔくことを試みたが， $\boldsymbol{u}^{n}$ の初 期解がある值以上になると資源存置数量 $\boldsymbol{q}^{n}$ の值が過大 になるなど, 操作変数, 状態変数について直感的に妥当 な解が得られなかった。つまり工程計画最適化問題に関 する限り SUMT・外点法, 共役こう配法の適用が必ず しも安定な数值解をもたらさない。一方, 図一6で得ら れた最適解を初期解として改めてSUMT ・ 外点法, 共役 こう配法を適用したところ，得られた解曲線は 図一8に 示すように $\boldsymbol{u}^{n}=\boldsymbol{v}^{n}=\mathbf{0}$ を初期解とした結果とは多少異 なり, また得られた操作変数, 状態変数の值にも多少の 差がみられた。すなわち SUMT・外点法による解は, その収束経路の影響をきわめて大きく受けることが分 る。さらに, 上述の操作により得られた解を初期解とし て改めて SUMT 計算を行うという操作を繰り返して ゆくと，上方に向って次々に少しずつ異なる解曲線が得 られ, Bryson・Denham の方法による解曲線の辺りでほ ぼ収束する。またおのおのの解曲線に伴う操作変数, 状 態変数の值はいずれも直感的に妥当である。したがって Bryson・Denham の方法による解曲線（上方から収束） が数值計算上, 真の最適解である可能性が強い。ただし Bryson・Denham の方法による解は，作業グループ投入 数量 $\boldsymbol{v}^{n}$ に対しては妥当な值を与えるが, 資源存置数量 $\boldsymbol{q}^{n}$ については, 後述する理由で必ずしも妥当な数值を 与えないので, 応用的にみて安定的な方法ではない。ま た上述の繰り返し計算を行らことも膨大な計算を必要と するので現実的な方法ではない。したがって現実の工程 計画最適化問題を解くためには, 操作変数と状態変数が 妥当な数值をもち, しかも Bryson·Denham の方法に よる出来高曲線を簡単に与える方法が必要になる。

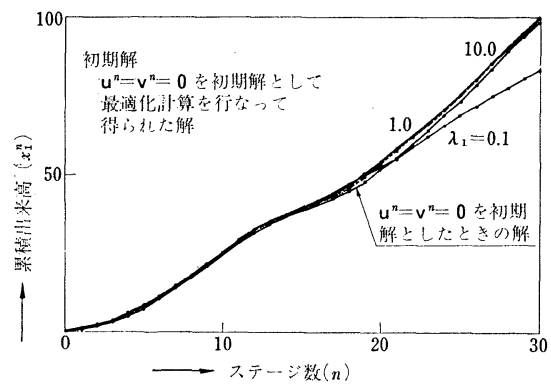

図-8

\section{（2）他のペナルティ関数法の適用}

a) SUMT $\cdot$ 内点法 ${ }^{25)}$

収束計算における前述の不安定性がおもに SUMT・
外点法に起因すると推察されるので, 他のペナルティ関 数法の適用について 検討する。 SUMT ・ 内点法は制約 条件式を満しながら，つまり制約領域の内側から境界に 近づく特性をもち, かつ外点法より ill-condition の影 響が小さいとされているので, 外点法の適用における前 述の問題を解決するために有効と推定されたが数值計算 は不成功であった。

b) SUMUP (Sequential Unconstrained Method Using Penalty) ${ }^{5), 44), 45)}$

詳細については省略するが, 佐山らにより提案された SUMUP は統一的な修正目的関数を定義することによ り, SUMT ・ 外点法, 内点法とそれぞれ似た特性をも たせることができる，より一般的なペナルティ関数法と されている。SUMUP の適用により，工程計画最適化 問題について SUMT ・ 内点法に近い収束計算を行うこ とができる。前述のように内点法の特性として制約領域 の内側から境界に近づくから，式（19）の影響により資 源存置数量 $\boldsymbol{q}^{n}$ は比較的大きな值から漸次減少して式 （19）の境界に近づく。作業グループ投入数量 $\boldsymbol{v}^{n}$ は式 (19)，（21）により，小さな值から漸増してその境界に 近づく。以上の経過をたぞって得られた解は $\boldsymbol{q}^{n}$ の值が 式（19）の境界に十分に近づかず（したがって不必要に 過大な值であり), 出来高曲線もまた図一6の解曲線よ りさらに下側で収束する。つまり SUMUPにより SUMT ・ 内点法に近い収束計算を行った場合にはわれ われの問題に関しては直感的に妥当な解が得られない。

$\mathrm{SUMT}$ ・外点法を用いて $\boldsymbol{u}^{n}=\boldsymbol{v}^{n}=\mathbf{0}$ を初期解とした 場合には, $\boldsymbol{q}^{n}$ の值が 0 からしだいに増加して最終的に 式（19）を満足するので，資源存置数量をできるだけ少 なくしようとする立場からの直感的に妥当な解が得られ ると解釈される。したがって,この観点からはSUMT ・ 外点法が工程計画最適化問題に最も適切なペナルティ関 数法と判断される。

\section{（3）工程計画最適化問題の特性}

a) アクティビティ順序関係の制約について

SUMUP, SUMT ・ 外点法における収束の様子につい て共通にみられる現象は，アクティビティ順序関係の制 約を表わす式 (22) に対応するペナルティの影響がきわ めて大きいことである。式 (29)，(30) から明らかなよ うに，他の制約条件に対応するペナルティ項がすべて 2 次関数であるのに, 式 (22) に対応する式 (30) は 4 次 関数である。したがって SUMT, SUMUP の後半段階 では, 式 (22) の制約によりみかけ上収束する恐れが強 い。SUMT ・ 外点法による解が前述のように収束経路 に大きく影響されることは上述の理由である可能性が強 い。 
また式（25）に示す 1 次元探索を行う場合には，操 作変数 $\boldsymbol{u}^{n}, \boldsymbol{v}^{n}$ に対する平均的意味での最良のステップ 幅しか与えられない゙から, 式 (30) に刘応するペナルテ ィの過大な影響のために SUMT, SUMUP の後半段階 では $\boldsymbol{v}^{n}$ が十分変化できず，したがって $\boldsymbol{u}^{n}$ も立た最適 解に十分近づけない恐れがある。 SUMT ・ 外点法の適 用に際しての初期解の与え方に関する不安定性, および SUMUP の適用に際して資源存置数量 $\boldsymbol{q}^{n}$ が式 (19) の境界に十分近づかない現象などは，その端的な例であ ろう。このように工程計画最適化問題が $\boldsymbol{u}^{n}, \boldsymbol{v}^{n}$ という 2 種類の性格の異なる操作変数 (決定変数) を含み, し かも $\boldsymbol{v}^{n}$ が式 (22) といら厳しい制約条件を伴っている ことが収束計算を不安定にしている原因と解釈される。

式 (22) による制約条 件を図示すると, 各変数 が図一9に拈ける太実線 土にある心をを要求す る, かなり苛酷な条件で ある。そこで式 (22) に よる制約の影響を何らか の方法により弱めること を検討する必要がある。 なお，明確に定義しなか ったが,アアクティビティ $j$ の先行アクティビティ の集合 $P_{j}$ としては, ア クティビティ $j よ り$ 先に

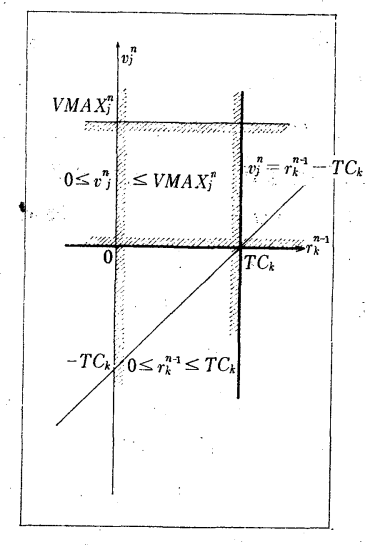

図-9
終了しなければならないすべてのアクティビティの集合 をとっている。 $P_{j}$ としてアクティビティ $j$ に直接先行 するアクティビティだけの集合をとることは好ましい数 值計算結果をもたらさない。

b) ペナルティ係数值比率の調整

アクティビティ順序関係の制約を表わす式 (22) に関 するペナルティを弱める方法として，たとえば次の $2 つ$ の案が考えられる。

(1) 順序関係の制約条件式を次式のいずれかで表わ す (図一 9 参照)。

$$
v_{j}^{n} \leq V M A X_{j}^{n} \cdot H\left[r_{k}{ }^{n-1}-T C_{k}\right], \quad\left(k \in P_{j}\right)
$$

$$
\min \left\{v_{j}^{n}, T C_{k}-r_{k}^{n-1}\right\}=0, \quad\left(k \in P_{j}\right)
$$

$$
\sqrt{v_{j}^{n}} \cdot \sqrt{T C_{k}-r_{k}^{n-1}}=0, \quad\left(k \in P_{j}\right)
$$

(2) 式 (33) において, 順序関倸の制約に対応するぺ ナルティ係数 $\lambda_{2}$ の值を $\lambda_{1}, \lambda_{3}$ の值より小さくする。

$$
\lambda_{2}=c \cdot \lambda_{1}=c \cdot \lambda_{3}, \quad(0<c<1)
$$

方法 (1) は数值計算がすべて不成功であった。方法 (2) として式 (43) における $c=0.1$ とし, $\boldsymbol{u}^{n}=\boldsymbol{v}^{n}=0$ を初
期解として SUMT · 外点法, 共 役こう配法を適用した結果を図一 10，11 に示す。図一11 で得られ た出来高曲線は明らかに上方から 収束しており，しかも Bryson • Denham の方法による解曲線にほ ぼ一致する。また, 得られた操作 変数, 状態変数の值はすべて直感 的に妥当であった。式 (43) にお ける $c=0.01$ として同じ操作を 行った結果を図一12,13 に示す。 図一13 に扔ける出来高曲線も上

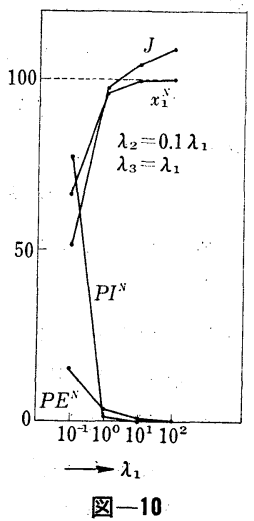
方から収束して抢り, 操作変数, 状態変数の值ともに妥 当であった。このようにペナルティ係数值の比率を変え て SUMT ・ 外点法, 共役こう配法を適用して得られた

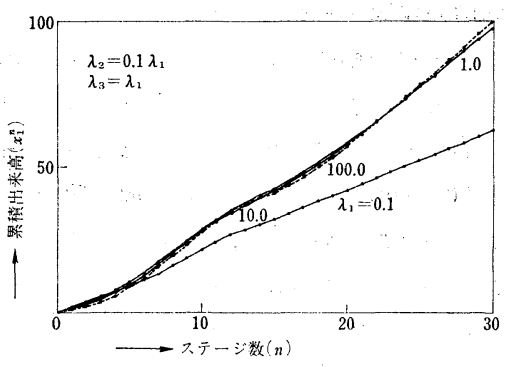

図-11

解曲線ををとめて 図一14 に示す。上述のように $c=0.1$ としたときの解曲線が Bryson・Denham の方法による 解曲線にほぼ一致しているから， この場合に数值計算上真の最適解 が得られている可能性が強い。 $c=0.01$ とした場合には上方か ら, $c=1.0$ とした場合には下方 から最適解に接近し, 真の最適解 に到達しえず, みかけ上収束した と推定される。しかし， $c=0.01$ または $c=1.0$ として得られた解 が全く意味がないかというとそう ではなく, 得られた操作変数, 状 態変数の值が妥当なものであるこ
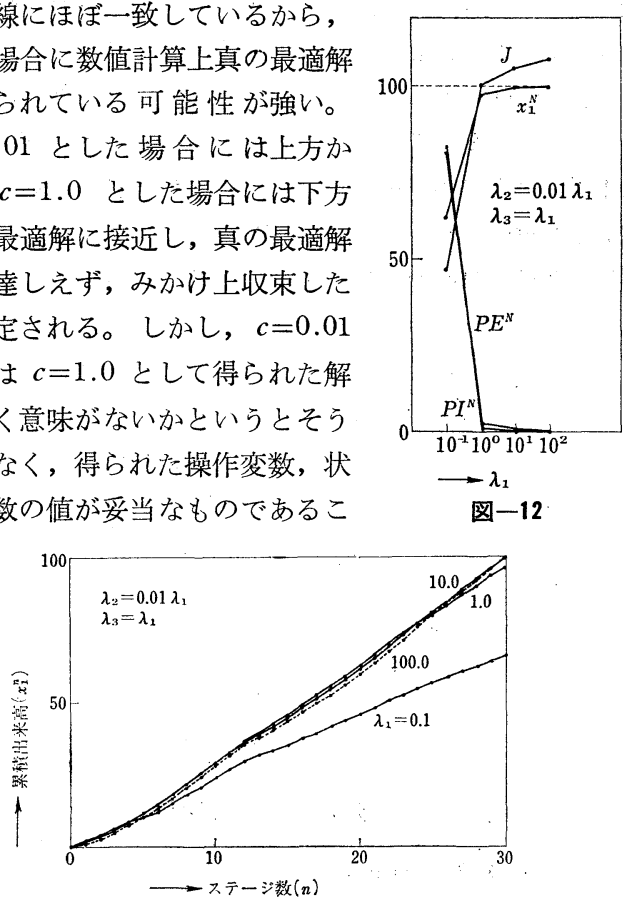

図-13 


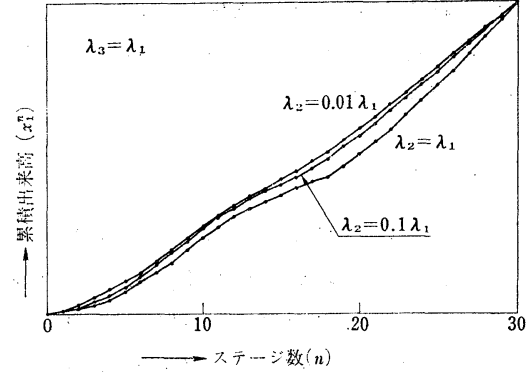

図-14

とから現実的な意味はもつわけであり,この点について は 5. で後述する。

なお，上方から収束する出来高曲線を得るといら観点 からすると，ペナルティ係数值の比率を次式のように与. える方法も考えられる。

$$
\lambda_{3}=d \cdot \lambda_{1}=d \cdot \lambda_{2}(d>1)
$$

上式に抢ける $d=10$ とし， $\boldsymbol{u}^{n}=\boldsymbol{v}^{n}=0$ を初期解として SUMT ・ 外点法, 共役しう配法を適用すると, 式 (43) における $c=0.1$ とした場合とほぼ同じ解が得られる (図一15)。

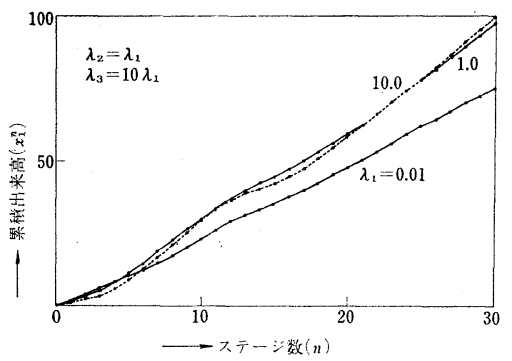

図-15

以上のことは本報で用いた数值計算モデルについて得 られた推論であるが，他の数值計算モデルについても同 様の結果が得られている。

\section{（4）静的最適化問題としての数值解析}

\section{a），静的最適化問題への変換}

工程計画最適化問題が多段決定過程（離散型最適制御 問題）として定式化されたから，そのまま関数空間にお けるこう配法, 共役こう配法を利用して前述の数值解析 を行った。しかし数值計算上は, 多段決定過程を静的

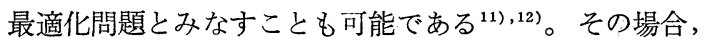
式（11）～(13）の状態方程式で表わされる状態変数をと り去って, 目的関数を操作変数のみにより表わして, 変 数空間での最適化手法を適用することができる。工程計 画最適化問題における状態方程式が式 (13) を除いてす べて線型なので，簡単に静的最適化問題に変換される。 たとえば式 (24) に対応する目的関数が次式で表わされ
る。

$$
\begin{aligned}
J & =\sum_{n=1}^{N}\left\{\sum_{i}\left(R C D_{i} \cdot \Delta T \cdot \sum_{m=1}^{n} u_{i}^{m}\right)\right. \\
& +R C I M_{i} \cdot V\left[u_{i}^{n}\right]+R C E X_{i} \cdot\left[-u_{i}^{n}\right] \\
& \left.+\sum_{i}\left(C W_{j}^{n} \cdot v_{j}^{n}\right)\right\}+\sum_{i}\left(R C E X_{i} \cdot \sum_{n=1}^{N} u_{i}^{n}\right) \rightarrow \min
\end{aligned}
$$

式（18)〜（22）の制約条件式も容易に操作変数のみによ

\section{り表わされる。}

\section{b）操作変数の変更}

先に定式化された工程計画最適化問題におけるよう に，資源搬入出数量 $\boldsymbol{u}^{n}$, 作業グループ投入数量 $\boldsymbol{v}^{n}$ を 操作変数 (決定变数) とする場合には, 静的最適化問題 とみても結局同じ操作を行うことになる。すなわち， 式（45）に制約条件式に関するペナルティ項を加えた修 正目的関数を, 各決定変数について微分して得られるこ う配は，式（34）（39）において共変変数を消去したも のと全く同一である。一方, 静的最適化問題とみなす場 合には，必ずしも $\boldsymbol{u}^{n}$ を決定変数とする必要はなく，資 源存置数量 $\boldsymbol{q}^{n}$ をそのまま決定変数としてさしつかえな い。

$$
\left.\boldsymbol{\theta}^{n}=\left(\begin{array}{c}
\boldsymbol{q}^{n} \\
\boldsymbol{v}^{n}
\end{array}\right), \begin{array}{l}
\boldsymbol{q}^{n}=\left(q_{1}{ }^{n}, \cdots, q_{M}{ }^{n}\right)^{T} \\
\boldsymbol{v}^{n}=\left(v_{1}{ }^{n}, \cdots, v_{L}{ }^{n}\right)^{T}
\end{array}\right\}
$$

このように操作変数を变更した問題に対して SUMT ・ 外点法, 共役こう配法を適用した場合の出来高曲線は, 図一13に示す出来高曲線よりさらに上側に収束する。 上述の方法では, 我々の関心の主詨象である資源存置数 量 $\boldsymbol{q}^{n}$ の直接的増分を評価することになるから，我々の 直感に近い解が得られる可能性の強いことを付記してお <。

c） ペナルティ関数法以外の解法について

式 (13) における $u_{i}{ }^{n}$ ，すなわち $q_{i}{ }^{n}$ に関する非線型 項は, $a_{i}{ }^{n}$ を図一16に示すように $a_{i}{ }^{n}, b_{i}{ }^{n}$ の 2 変数に 分けることにより線型関数として表わされる。

$$
\left.\begin{array}{l}
\boldsymbol{\theta}^{n}=\left(\begin{array}{c}
\boldsymbol{a}^{n} \\
\boldsymbol{b}^{n} \\
\boldsymbol{v}^{n}
\end{array}\right), \begin{array}{l}
\boldsymbol{a}^{n}=\left(a_{1}{ }^{n}, \cdots, a_{M}{ }^{n}\right)^{T} \\
\boldsymbol{b}^{n}=\left(b_{1}{ }^{n}, \cdots, b_{M}\right)^{T} \\
\boldsymbol{v}^{n}=\left(v_{1}{ }^{n}, \cdots, v_{L}{ }^{n}\right)^{T}
\end{array}
\end{array}\right\}
$$

この操作は, $q_{i}{ }^{n}$ に関する目的関数が 図一16 に示すよ うに下に凸であり，かつ最小化問題であることを考慮す ると, 凸性を損うものではなく, 決定変数の個数が増加 することを除いて数值解析上の不利益をもたらさないこ とが明らかである。したがって, 静的最適化問題とみな した工程計画最適化問題における制約条件式, 目的関数 が, 式 (22) に相当する制約条件式を除いてすべて線型 関数により表わされた。離散型最適制御問題とみた場合 の工程計画最適化問題が状態変数制約問題となることか ら, 制約条件式の処理はペナルティ関数法以外に実際的 
方法が与えられていない。しかし，ペナルティ関数法に よると近似解しか与えられず，また前述のような不安定 な問題も生じる。一方, 静的最適化問題とみて上述の線 型性に注意すると,ペナルティ関数法以外に多くの手法

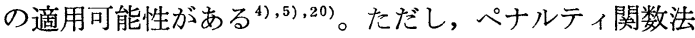
以外の非線型計画法のほとんどが多量の記憶容量を必要 とし，乙かも決定変数の個数の次元をもつ逆行列計算を 必要とするものが大半であることから, 決定変数の個数 のきわめて大きい工程計画最適化問題にこれらの手法を 適用することが現段階では困難であろう。今後の非線型 計画法の発展に応じて, 上述のような工程計画最適化問 題の特性に注目した，より計算量の少ない,より安定的 な手法を開発することが実際的な応用のための課題の 1 つである20),46)。

\section{5．工程計画管理業務への忘用}

\section{（1）基本的な方針}

工程計画最適化問題の定式化に際して強調したよう に，計画管理業務の合理化に扝ける基本的目標は，業務 担当者が正確な意志決定を行うための合理的な判断資料 を提供することである。つまり，定量的に評価しうる要 素間の関係を数式で表わして最適化計算を行い，その結 果に対して, 定量的に評価しにくい要素についての配慮 が加えられることにより合理的な決定を行うことができ ると考えた。この考え方に基づいて，工程計画管理にお いて定量的に評価しうる種々の要素間の関係を制約条件 式の形で表現した上で，全体費用 $\rightarrow$ 最小という評価基隻 のもとに施工段取を決定する問題として工程計画最適化 問題を定式化した ${ }^{2)}$ 。また，このことから工程計画最適 化問題の解が，こう配法の適用に際して述べたように， 施工段取すなわち，機械，労務などの資源工程計画表， および作業工程計画表の形で与えられることを強調して おく ${ }^{3)}$ 。さらに，次節で述べるように最小費用の施工段

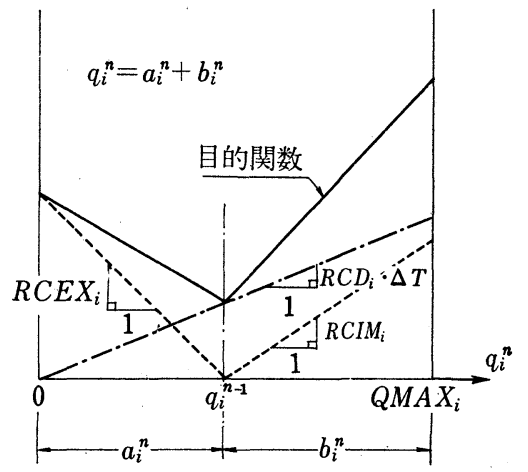

図-16
取に裏つけられた工期一費用曲線を作成することによ り，より広範な施工計画管理における合理的な意志決定 を行うことを提案している ${ }^{2)}$ 。

\section{（2）工期一費用曲線}

本報で用いた数值計算モデルについて工期 $T$ すなわ ち全ステージ数 $N$ を変えて最適化計算を繰り返すこと により，図一17 に示すように各工期に対応する（最小費 用の施工段取に裏づけられた）工事経路が得られる。こ れらの工事経路の最終点を結んだものが，最小費用の施 工段取に裏ゔけられた工期一費用曲線である2゙。ただし 図一17 は資源存置数量，作業グループ投入数量などが SUMT ・ 外点法, 共役こう配法により実数解として与え られた場合の工事経路をそのまま描いたものでありここ れらの変数を整数解に調整した場合には工事経路が多少 変化するであろう。また，筆者の定式化では，たとえば 現場管理費用などの間接的費用を考慮していないから， 本来の意味での工期一費用曲線を得るためには 図一17 に示すようにこれらの費用に対する配慮を加える必要が ある。

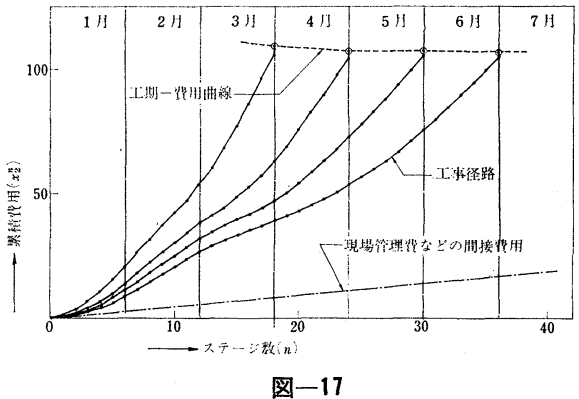

このようにして得られる工期一費用曲線を用いて，マ クロなレベルで CPM (Critical Path Method) を適用 しうる可能性がある。すなわち, 工程上の資源操作方法 に対する配慮が不必要な比較的マクロなレベルで, CPM に打ける作業（アクティビティ）を設定するならば，そ の作業（アクティビティ）を，本報の手法における工事 (Project) とみなすことができる。そして，CPM にお ける各々のアクティビティについての「時間一費用関 係」を，上述の最小費用の施工段取に裹づけられた工期 一費用曲線で与えて CPM を適用することは十分に妥 当な意味をもつことである。

\section{（3）出来高曲線の型}

前述の，工程計画管理における定量的に評価しにくい 要素の例として，たとえば出来高曲線の型があげられ る。図一18 に示すように，工程の前期において出来高 曲線が立ち上がる場合を前半進捗型，逆の場合を後半進 


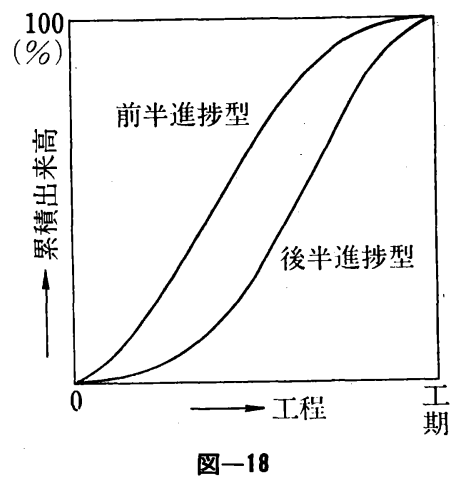

捗型と称しよう。実際の工程計画に際しては, この出来 高曲線の型について業務担当者の経験的判断などに基う く選好性が存在すると想像される。つまり, 出来高曲線 の型の選択に際して, 施工の確実性, 安定性などのよう に量的に表わしにくい要素に対する考慮が必要になるで あろ5。一方, 図一14について前述したように, ペナ ルティ係数值の比率を調整することにより異なる出来高 曲線が得られる。図一14 に括いて $\lambda_{2}=0.1 \lambda_{1}$ とした場 合の絬果が数値計算上は最も妥当な解であると推定され たが，その他の結果が必ずしも無意味ではないことを指 摘しておいた。すなわち, ペナルティ係数值の比率を調 整することにより, 逆に上述のような前半進捗型, 後半 進捗型の出来高曲線が任意に与えられる可能性がある。 ただし, 実際の工程計画において，一般的にペナルティ 係数值にどのような比率を与えるのが妥当であるかにつ いては今後多くの工事に適用した上で検討しなければな らない。

\section{（4）応用上の課題}

建設工事の工程計画管理がきわめて多面的な要素を含 むことから，前述のように定量的に評価しうる要素だけ を考慮して最適化計算を行らにしても, 計画, 管理を行 う立場によっては，筆者の定式化において考慮した以外 の要素を考慮する必要があろう。したがって, 式(18)〜 （22）の他に制約条件式を付加したり，あるいは式 (13) の費用計算方法を修正するなど, 実際の応用に際して検 討が必要な問題も多数残されていると想像される。一連 の報告における筆者の基本的意図が, 施工計画, 管理に おける種々の要素を一般的に表現する方法を与えること であったために，考慮した制約条件式などは一般的なも のだけに限られている。実際の工事一の応用を計るには 組織的研究により,さらに具体的な検討が行われる必要 がある。

\section{6. 結}

\section{論}

得られた主な結果は次のとおりである。

（1）多段決定過程として定式化された機械化土工に おける工程計画最適化問題に対して, 先に最適制御理論 におけるこう配法を用いた数值解析を行い，現実的な数 值解が得られることを示した。本報では共役こう配法を 用いて, より詳細な数值解析を行った結果, 実際の工事 に対して費用の評価に基づく工程計画の選定（動的見積 り）作業を行ら準備が整えられた。

（2）SUMT・外点法により制約条件のない最適化 問題に変換された工程計画最適化問題に対して, 共役こ ら配法を用いた収束計算を行なった結果, この問題に対 しても共役こう配法が計算効率の面でこう配法に比べて 格段に優れていることが示された。また，共役こう配法 の適用に際して, 1 次元探索その他に関する詳細な検討 が行われた。

（3）こう配法により得られた出来高曲線と共役こう 配法による結果との比較を行い，さらに SUMT · 外点 法, 共役こう配法を適用し、て, 解空間の特性に関する検 討を行った。この結果, SUMT ・外点法, 共役こう配 法による方法が初期解の与え方に関して必ずしも安定で はないことが示された。

（4） SUMUP, 共役こう配法による数値解析の結果, 工程計画最適化問題における資源搬入出数量 $\boldsymbol{u}^{n}$, 作業 グループ投入数量 $\boldsymbol{v}^{n}$ といら 2 種類の操作変数の存在が 収束計算を不安定にしていることが明らかにされた。ま た, この点に関しては SUMT ・ 外点法を適用して, 初 期解を $\boldsymbol{u}^{n}=\boldsymbol{v}^{n}=\mathbf{0}$ とする方法が有利であることも明ら かにされた。

（5） SUMUP, SUMT ・ 外点法による収束計算にみ られる共通の現象として,アクティビティ順序関係の制 約条件式に対応するペナルティ項の影響が過大であるこ とから, 真の解に到達する以前にみかけ上収束する可能 性が指摘された。この現象を防ぐために，それぞれの制 約条件式に対応するペナルティ係数值の比率を調整する ことが有効であることが明らかにされた。また，このぺ ナルティ係数值比率の調整により, 出来高曲線の型を操 作しうる可能性が示された。

（6）多段決定過程として定式化された工程計画最適 化問題に対して, 静的最適化問題としての数值解析を行 う.可能性が示された。

（7）以上の結果として, SUMT ・ 外点法, 共役こう 配法を利用することにより，現実の工事に対して動的見 積り作業を行う数值計算上の基礎が与えられた。すなわ ち, 在庫管理, スケジューリング問題などを含む複雑な 意志決定を業務担当者自身が行わなくても, 基本的なデ 一タを与えるだけで, その条件のもとでの最小費用の施 工段取に裏づけられた工程計画案が自動的に得られるこ 
とになり，施工計画・管理業務の合理化に寄与しうると 推察される。

本報で述べた方法は機械化土工だけでなく，工程上の 資源操作が施工計画・管理における支配的な要素となる 一般的な建設工事に対して利用できることとが明らかで ある。本報で得られた結果に基づいて, 害際の施工計画 ・管理業務のシステム化を検討することが今後に残され た課題である。

\section{7.あとがき}

従来, 施工計画・管理業務の合理化が要請されながら も目立った進展がみられていない。その原因の 1 つとし て, 施工に抢ける多面性, 不確実性などに起因する複雑 な要素を客観的, 合理的に表現しえていないことがあげ られる。すなわち, 経験的にしても実際に施工現象を把 握している業務担当者と, 施工計画 - 管理業務の合理化 を担当するシステム開発者の間には，互いに情報を交換 し合うための有効な表現手段が現時点では確立されてい ない。たとえばネットワーク手法だけでは，施工におけ る多面的な要素を正確に表現することが困難である。筆 者の一連の報告は上述の意味で, 施工計画・管理に対す る 1 つの基礎的な表現手段を与えることを目標としたも のである。前述のように, 定量的に評価しにくい要素に ついては, 業務担当者の最終的判断に委ねることにし, 定量的に評価しうる要素間の関係を多段決定過程として 制約条件式と目的関数の形で表わした。すなわち, 工程 計画最適化問題を “与えられた工法, 工期のもとでの最 小費用の施工段取案の選定” として定式化し, 最終的に は,この最小費用の施工段取に裹づけられた工法一工期 一費用の関係を求めることにより合理的な意志決定を行 らことを提案した。本報で得られた結果により，現実の 大型建設工事に対して上述の動的見積り作業を行うため の数值計算上の基礎が与えられた。筆者は本報で述べた 手法をいくつかの実際の建設工事に適用して満足寸べき 結果を得ている。ただし，施工計画・管理業務に対する 筆者の経験不足のために, 考虑した要素や定式化の方法 などに関して多くの問題が残されていると想像される。 これらの問題については，実際の工事に対して上述の手 法の適用実績を積み重ねた上で, 種々の面から検討が加 えられなければならない。今後このような観点からの批 判や指摘を期待寸る。

最後に, この研究の遂行に際してご指導とご助力をい ただいた京都大学工学部土木工学教室 畠昭治郎教授, 同太田秀樹助教授, および鹿島建設（株）多田義雄常務 取締役をはじめとする同土木見積部，同電子計算センタ 一同技術研究所 有泉 昌室長をはじめとする同企画調
查室の諸氏に感謝の意を表します。

\section{参考 文 献}

1）唣・荒井：土工機械の待合せに関する基礎的考察，土木 学会論文報告集, No. 194, pp. 127-140 (1971).

2）庄子・荒井：機械化土工における工程計画管理最適化問 題の定式化, 土木学会論文報告集, No. 214 , pp. 57-70 (1973).

3）庄子・荒井：こう配法による機械化土工・工程計画管理 の最適化, 土机学会論文報告集, No. 215, pp. 61-74 (1973).

4) 志水：システム制御と数理計画法, コロナ社（1970）

5) 高松編 : プロセスシステム工学, 日刊工業新聞社 (1972)

5) A.P. Sage : Optimum Systems Control, Prentice Hall (1968).

7) A.E. Bryson, and Y.C. Ho : Applied Optimal Control, Ginn (1969).

8) M.M. Denn : Optimization by Variational Methods, McGraw-Hill (1969).

9) E. Polak : Computational Methods in Optimization; A Unified Approach, Academic Press (1971).

10) P. Dyer, and S.R. Mcreynold : The Computation and Theory of Optimal Control, Academic Press (1970).

11) M.D. Canon, D. Cullum and E. Polak : Theory of Optimal Control and Mathematical Programming, McGraw Hill (1970).

12) D. Tabak and B.C. Kuo ; Optimal Control by Mathematical Programming, Prentice-Hall (1971).

13) J. Kowalik and M.R. Osborne (山本他訳) : 非線形最 適化問題, 培風館 (1970).

14) 片岡 : 数理計画法, 東洋経済 (1971)

15） O.L. Mangasarian (関根訳) : 非線形計画法, 培風館 (1972).

16） C. McMillan（前田他訳）：数理計画入門 (上・下), 東京 図書 (1972).

17) D.J. Wielde : Optimum Seeking Methods, PrenticeHall (1964).

18) G. Hadley : Nonlinear and Dynamic Programming, Addison-Wesley (1964).

19) G.S.G. Beveridge and R.S. Schechter : Optimization; Theory and Practice, McGraw-Hill (1970).

20) D.M. Himmelblau : Applied Nonlinear Programming, McGraw-Hill (1972).

21）佐山・大井 : 非線形計画法とその応用例, 制御工学, Vol. 11, No. 11, pp. 565-573 (1967).

22）佐山：グラジェント法によるプロセスの最適化, 化学機 械技術, 第 21 集, pp. 133-157, 丸善 (1969).

23) D.E. Johansen: Convergence Properties of the Method of Grodients, Advance in Control Systems, Vol. 3, pp. 279-316 (1966).

24) D.G. Luenberger : Convergence Rate of A Penalty. Function Scheme, J. of Optimization Theory and Applications, Vol. 7, No. 1, pp, 39-51 (1971).

25) A.V.Fiacco and G.P. Mccormick : Nonlinear Programming; Sequential Unconstrained Minimization Techniques, John Wiley (1968).

26）佐山・大井 : こう配法のプロセス最適化への応用, 計测 と制御, Vol. 9, No. 10, pp. 725-739 (1970).

27）市川: 最適制御の計算アルゴリズム, 日本機械学会誌, Vol. 74, No. 631, pp. 1026-1035 (1971).

28）市川・田村: 最短時間制御問題の解法 [I], 計測と制御, Vol. 12, No. 5, pp. 409-422 (1973).

29）高松・佐山・大井：グラジェント法における 1 次元探索 に関する一考察, 制御工学, Vol. 13, No. 9, pp. 596- 
604 (1969).

30) H.J. Kelley : Gradient Theory of Optimal Flight Paths, ARS J., Vol. 30, pp. 947-954 (1960).

31) A.E. Bryson and W.F. Denham : A Steepest-Ascent Method for Solving Optimum Programming Problems, J. Applied Mechanics, Vol. 29, pp. 247-257 (1962).

32) R. Fletcher and C.M. Reeves : Function Minimization by Conjugate Gradient, Computer J., Vol. 7, pp. 149 -154 (1964).

33) L.S. Lasdon, S.K. Mitter and A.D. Waren : The Conjugate Gradient Method for Optimal Control Problems, IEEE Trans. on Automatic Control, Vol. AC-12, No. 2, pp. 132-138 (1967).

34) B. Pagurek and C.M. Woodside : The Conjugate Gradient Method for Optimal Control Problems with Bounded Control Variables, Automatica, Vol. 4, pp. 337-349 (1968).

35) J.K. Willoughby and B.L. Pierson : A Constraint-Space Conjugate Gradient Method for Function Minimization and Optimal Control Problems, Int. J. Control Vol. 14, No. 6, pp. 1121-1135 (1971).

36) T.S. Fong and C.T. Leondes : Method of Conjugate Gradients for Optimal Control Problems with State Variable Constraint, Advance in Control Systems, Vol. 7, pp. 1-22 (1972).

37) R. Fletcher, and M.J.D. Powell : A Rapidly Convergent Decent Method for Minimizaton, Computer J., Vol. 6, pp. 163-168 (1963).

38) L.B. Horwitz and P.E. Sarachik : Davidon's Method in
Hilbert Space, SIAM J. Math., Vol. 16, No. 4, pp. 676-695 (1968).

39）市川：機械技術者のための最適制御入門，日本機械学会 (1972).

40）黑田：状態に制限のある制御采の最適制御，システムと 制御, Vol. 15, No. 3, pp. 73-79 (1971).

41) J. Mcintyre and B. Paiewonsky : On Optimal Control with Bounded State Variables, Advance in Control Systems, Vol. 5, pp. 389-419 (1967).

42) M.M. Lele and D.H. Jacobson : A Proof of the Convergence of the Kelley-Bryson Penalty Function Technique for State-Constrained Control Problems, J. Mathematical Analysis and Applications, Vol. 26, pp. 163-169 (1969).

43) L.S. Lasdon and A.D. Waren, R.K. Rice : An Interior Penalty Method for Inequality Constrained Optimal Control Problems, IEEE Trans. on Automatic Control, Vol. AC-12, No. 4, pp. 388-395 (1967).

44）佐山・畠山：状態制約をうける最適制御問題に対するぺ ナルティ法, 第 11 回計測自動制御学会学術講 演 会予稿 集, pp. 305-312 (1972).

45）伎山・尾添・㫣山：非線形計画問面に対するペナルティ 法, 計測自動制御学会論文集, Vol. 9, No. 1, pp. 100107 (1973).

46) R.K. Mehra and R.E. Davis : A Generalized Gradient Method for Optimal Control Problems with Inequality Constraints and Singular Arcs, IEEE Trans. on Automatic Control, Vol. AC-17, No. 1, pp. 69-79 (1972).

(1974.4.18 - 受付) 